\title{
Study of Iron, Inorganic Phosphate, Sodium, Potassium in Serum and its Effects on Reproduction of the Experimental Fish Clarias Batrachus
}

\author{
Dr. Amit Kumar
}

University Department of Chemistry, B. R. A. Bihar University, Muzaffarpur, Bihar, India.

E-mail: thisisamitsingh@yahoo.co.in

\begin{abstract}
Article Info

Volume 7, Issue 5

Page Number: 307-314

Publication Issue :

September-October-2020

\section{Article History}

Accepted : 15 Oct 2020

Published : 27 Oct 2020

Reproduction is a natural phenomenon governed by both the endocrine (intrinsic) and climatic (extrinsic) factors. The intrinsic factors mediate their effects through the hypothalamo-hypophysial-Gonad sub system operating as an organic axis bridging the ecological influence and Gonadal maturation. Temperature, light, rainfall etc. of the habitat and food supply appear to the predominant external factors influencing breeding periodicity, whereas, the condition of the Gonads and their secretions \& the general condition of the body are the internal features which influence the physiology \& psychology of the breeders to make the target organs responsible to external influences (Malhotra et.al., 1989). Among the climatic factors, temperature and/or day length (Photoperiod) are generally recognized as the most important cues in the timing of gametogenesis in fish species of temperate zone (Gillet et.al., 1978) but in sub-tropical region, when seasonal variations in the day length \& temperature are relatively small both affects Gonadal recrudescence. In this paper we determine the Iron, Inorganic Phosphate, Sodium, Potassium in Serum and its Effects on Reproduction of the Experimental Fish Clarias Batrachus.
\end{abstract}

Keywords: Protein, Glucose, Albumin, Globulin, Fish, Clarias Batrachus (Linn).

\section{INTRODUCTION}

In tropical \& sub-tropical regions, the peak spawning activity in the fish is often associated with flood, rainfall \& lunar cycles (Schwassmann, 1971, 1980; Liley, 1980), but it is still not clear that which one of the terminal reproductive events i.e. oocyte maturation, ovulation or oviposition is enhanced by rainfall or whether spermiation is involved.

Temperature dependent seasonal variations of the electrophoretic protein patterns were demonstrated by Schlotfeldt (1975), whereas, other workers (Haider, 1970b; Perrier et al. 1973a) could not observed any change in Salmo guairdneri. Increasing water temperature enhances the metabolic activities in most of the fish species,

Copyright: (C) the author(s), publisher and licensee Technoscience Academy. This is an open-access article distributed under the terms of the Creative Commons Attribution Non-Commercial License, which permits unrestricted noncommercial use, distribution, and reproduction in any medium, provided the original work is properly cited 
which reflects on numerous plasma constituents especially the enzymes like LDH, GOT, GPT etc. in which activities increased with rising temperature to two to five times normal values, but alkaline phosphate (AL) \& Lucin-peptide-hydrolase (LAP) decreased (Bouck et al. 1975; Sauer \& Haider, 1977). However, most of the aforesaid works have been done on the Salmo guairdneri and other fish of temperate zone. Such studies on Indian fresh water fish is lacking.The male reproductive system in most of the teleosts is mainly comprised of parried testes, lie in the posterior-dorsal part of the body cavity, ventral to kidneys along the length of the body cavity. The lumen of the testes in divided in to large number of lobules or somniferous tubules, which undergo changes in accordance with maturity cycle (Ghosh \& Kar, 1952; Srivastava, 1967; Agarwal, 1982). Similarly, the female reproductive system is mainly comprised of paired, elongated ovaries, placed along the ventro-lateral aspects of the body cavity and may be of gymnovarion or cystovarian type. Each ovary is hollow \& the lumen is filled up with oocytes of different states of maturation. The ovarian cycle in almost all freshwater fish follows a more or less identical pattern of maturation (Ghosh \& Kar, 1952; Sathyanesan, 1959; Guraya et.al., 1975; Agarwal, 1982, Singh, 1990; Gupta, 1996).

Further, it is also well known that both testes \& ovary gets nutritive substances from different organs like liver \& muscle through the blood during their developmental cycle, but the detailed inter-relationship between the various constituents of blood and reproductive organs are yet not clearly understood \& hence needs further studies on this aspect.

\section{EXPERIMENTAL}

The weight, length and place of collection were maintained same during the experiment just to avoid the impact of these variables, if any, on the biochemical parameters of the fish. Identification of the fish was based upon Berg (1940).

$\begin{array}{lll}\text { Series } & - & \text { Pisces. } \\ \text { Class } & - & \text { Teleostomi } \\ \text { Order } & - & \text { Cypriniformes } \\ \text { Division } & - & \text { Siluri } \\ \text { Sub-order } & - & \text { Siluroida } \\ \text { Family } & - & \text { Clariidae } \\ \text { Genus } & - & \text { Clarias } \\ \text { Species } & - & \text { Clarias batrachus (Linnaeus) }\end{array}$

After collection, fish were brought to the research laboratory using the water of the lake, and kept in glass aquaria (100 x $40 \times 40 \mathrm{~cm}$. size) containing tap water for 1-2 weeks to acclimatize the fish prior to each experiment.

The average day length and temperature were recorded after averaging the timing of Sun-rise and Sun-set of each day of the month and by averaging the temperature taken thrice on every third day of the month during 
the year 2014 respectively. The average rainfall data was obtained from the local Govt. Meteorological observations station at Pusa, Samastipur.

After 7 to 10 days of acclimation, the body weight and length of at least ten fish for each sex (male and female) were measured, followed by measuring the weight and length of testes \& ovary of the fish. The average values thus obtained, were recorded for each month of the year. The Gonadal index (G.I,) and gonadosomatic index were calculated for all above mentioned fish individually using the following formulae and the average value was recorded for each month.

$$
\begin{aligned}
& \text { G.I. }(\mathrm{gm} / \mathrm{cm})=\begin{array}{l}
\text { Weight of Gonad }(\mathrm{gm}) / \text { Length of Gonad }(\mathrm{cm}) \\
\text { Weight of Gonad }(\mathrm{gm})
\end{array} \\
& \text { G.S.I. }=\frac{\text { Weight of Fish }(\mathrm{gm})}{\text { W }} \times 100
\end{aligned}
$$

The blood of male \& female fish were pooled separately either by Caudal vessel or directly by heart puncture and serum were collected after proper clotting of blood \& centrifuging the same. Accordingly, five sample of each sex were prepared for biochemical determination of various parameters.

\subsection{Determination of Iron in Serum}

\section{Reagents used:}

(i) $25 \%$ Sod. Thiocyanate sol. 25 gm sod. Thiocyanate was dissolved in minimum amount of distilled water. To this, $2 \mathrm{ml}$ Acetone was added \& made up to $100 \mathrm{ml}$ with distilled water. Stored in refrigerator.

(ii) $\quad 70 \%$ Perchloric acid (A.R.) containing 0.5 to $2.0 \mathrm{mg}$ iron $/ \mathrm{ml}$.

(iii) Conc. $\mathrm{H}_{2} \mathrm{SO}_{4}$ (Sp. Gr. 1.84) A.R.

(iv) n-Amyle Alcohol A.R.

(v) Saturated Pot. Persulphate (8 gm Pot. Persulfate $+100 \mathrm{ml}$ water dist.).

(v) Stock iron standard $(0.5 \mathrm{mg} / \mathrm{ml}): 3.51 \mathrm{gm}$ of Mohr's salt $\left[\left(\mathrm{NH}_{4}\right)_{2} \mathrm{SO}_{3} . \mathrm{FeSO}_{4} .6 \mathrm{H}_{2} \mathrm{O}\right]$ was dissolved in 100 $\mathrm{ml}$ of distilled water. To this $2 \mathrm{ml}$ of conc. $\mathrm{H}_{2} \mathrm{SO}_{4}$ was added and after ceasing of foaminl. $100 \mathrm{ml}$ of Sat. Pot. Persulphate sol. (Supernatant) was added and diluted to 1 liter.

\section{Procedure:}

$0.2 \mathrm{ml}$ of unhaemolyzed serum was mixed with $0.4 \mathrm{ml}$ of conc. $\mathrm{H}_{2} \mathrm{SO}_{4}$ in a pyrex/Borosil hard glass test tube. Digested on a medium heated hot plate until all activities ceases. To this, $0.5 \mathrm{ml}$ of perchloric acid (70\%) was added and heated until clear. Now, $5 \mathrm{ml}$ of distilled water and $0.2 \mathrm{ml}$ of pot. Persulfate sol. was mixed and cooled to room temperature. After cooling, $1 \mathrm{ml}$ of sod. Thiocyanate sol. was added \& mixed properly. To this, $3 \mathrm{ml}$ of amyle alcohol (colorless) was added \& mixed vigorously for 30 seconds. Centrifuged and supernatant amyle alcohol layer was read in colorimeter at 530 filter. 
$0.02 \mathrm{ml}$ of standard iron solution was also processed as above as standard and distilled water was used as blank.

The OD, thus, obtained for sample and standard were calculated as follows to get iron content.

O.D. of Unknown

Calculation:

O.D. of Standard

\subsection{Determination of Inorganic Phosphate in Serum}

\section{Reagents used:}

(i) $\quad 10 \%$ Trichloro acetic acid (TCA).

(ii) $\quad 2.5 \%$ Acid molybdate sol. : $8.3 \mathrm{ml}$ of conc. $\mathrm{H}_{2} \mathrm{SO}_{4}$ was added slowly in $40 \mathrm{ml}$ of water. To this, $2.5 \mathrm{gm}$ Ammonium molybdate was dissolved \& made upto $100 \mathrm{ml}$ with distilled water.

(iii) Reducing reagent: 14.6 gm $\mathrm{NaHSO}_{3}$ and $0.5 \mathrm{Na}_{2} \mathrm{SO}_{3}$ was dissolved in $150 \mathrm{ml}$ distilled water. To this, 0.1 gm of powdered 1-Amino-2 Naphthol-4 sulphonic acid was added and mixed till dissolved. Filtered with activated charcoal \& kept in a brown bottle.

(iv) Phosphate standard $(10 \mathrm{mg} / 100 \mathrm{ml}): 219 \mathrm{mg} \mathrm{KH}_{2} \mathrm{PO}_{4}$ (dried at $80^{\circ} \mathrm{C}$ overnight \& cooled in dessicator) was dissolved in $500 \mathrm{ml}$ of water \& kept under toluent.

(v) Working phosphate standard $(1 \mathrm{mg} / 100 \mathrm{ml})$.

$1 \mathrm{mg}$ of phosphate standard was diluted to $100 \mathrm{ml}$ with distilled water.

\section{Procedure:}

$0.05 \mathrm{ml}$ of serum was taken into $0.5 \mathrm{ml}$ of water in first test tube (T) while in second test tube (S) $0.05 \mathrm{ml}$ of working standard was taken in place of serum. To both tubes, $1 \mathrm{ml}$ of $10 \%$ TCA was added separately. Mixed and allowed to stand for 5 minutes. Centrifuged. $1 \mathrm{ml}$ of aliquote of the clear supernatant was taken separately from each tube. To each test tube, $0.5 \mathrm{ml}$ of acid molybdate reagent was added, mixed and then $0.5 \mathrm{ml}$ of reducing agent was added. Mixed well \& allowed to stand for 30 minutes. For blank, $0.5 \mathrm{ml}$ distilled water was mixed with $1 \mathrm{ml}$ of $10 \%$ TCA \& $1 \mathrm{ml}$ of aliquote of this sol. was taken. Both test \& standard sol. were read in colorimeter at 660 filters.

OD of Test

Calculation: — X $4=\mathrm{mg}$ phosphorus $/ 100 \mathrm{ml}$. serum

OD of Standard 


\subsection{Determination of Sodium in Serum}

\section{Reagents used:}

(i) Uranyl zinc acetate sol. : (a) 7.7 gm of Uranyl acetate and $1.4 \mathrm{ml}$ of glacial acetic acid were dissolved in $40 \mathrm{ml}$ of distilled water by stirring \& heating on a steam bath. It was then diluted to $50 \mathrm{ml}$ with water. (b) $32.1 \mathrm{gm}$ zinc acetate and $0.7 \mathrm{ml}$ glacial acetic acid were also dissolved $40 \mathrm{ml}$ of water as above \& then diluted to $50 \mathrm{ml}$ with water. Both (a) \& (b) were mixed while hot \& allowed to stand for $24 \mathrm{hr}$. \& then filtered.

(ii) Acetone wash reagent: $15 \mathrm{ml}$ of above solution (Uranyl zinc acetate) was mixed with $1 \mathrm{ml}$ of $5 \%$ Aq. $\mathrm{NaCl}$ sol. and about $5 \mathrm{ml}$ of $95 \%$ Alcohol was added in portions. Filtered by suction and precipitate was washed by five small portions of $95 \%$ alcohol and then five small portions of ether. During each wash ppt was made dry by suctioning. This amount of the triple salt was added to 1 litre of acetone shaken \& left overnight and filtered.

(iii) Standard sodium soln. $1 \mathrm{gm}$. of sod. Chloride was dissolved in water and made upto 1 liter. Thus each $\mathrm{ml}$ of this solution contained $0.393 \mathrm{mg}$. of sodium.

\section{Procedure:}

$0.1 \mathrm{ml}$ of serum was mixed with $0.7 \mathrm{ml}$ of distilled water. To this $0.2 \mathrm{ml}$ of $20 \%$ TCA was added with shaking. Left for 10 minutes and centrifuged. $0.5 \mathrm{ml}$ of the filtrate was taken in a centrifuge tube and $5 \mathrm{ml}$ of Uranyl zinc acetate solution was added. This, $0.3 \mathrm{ml}$ of $95 \%$ alcohol was added with one ml graduated pipette and left stand for 5 minutes. This process was repeated 6 times untill a total of $2.1 \mathrm{ml}$ of $95 \%$ alcohol was added. Centrifuged \& precipitate was taken, by inverting the tube on a pad of filter paper \& wiped the mouth of the centrifuge tube. The precipitate was again washed with $10 \mathrm{ml}$ of acetone wash reagent, centrifuges as above \& precipitate was then transferred to a $100 \mathrm{ml}$ Erlenmeyer flask by blowing in three or four $5 \mathrm{ml}$ portions of water (recently boiled \& cooled to drive off dissolved $\mathrm{CO}_{2}$ ). Now add $50 \mathrm{ml}$ of aforesaid water \& $0.5 \mathrm{ml}$ of $1 \%$ phenopthelin solution and titrated with $0.02 \mathrm{~N} \mathrm{NaOH}$ using a graduated micro burett. Simultaneously a blank was run to determine the amount of $0.02 \mathrm{~N} \mathrm{NaOH}$ which just to give the end point (pink colour) with distilled water.

Calculation: $\quad$ As $1 \mathrm{ml}$ of $0.02 \mathrm{~N} \mathrm{NaOH}$ is equivalent to $0.0575 \mathrm{mg}$ of sodium in the sample.

Therefore, $\mathrm{mg} \mathrm{Na} / 100 \mathrm{ml}$ serum = Titration Blank X0.0575 X 100/0.1

\subsection{Determination of Potassium in Serum}

\section{Reagents used:}

(i) $\quad 1.5 \%$ Aq. Sod. Tungstate solution.

(ii) $\quad 2.5 \%$ Aq. $\mathrm{CuSO}_{4}$ solution.

(iii) $2.5 \%$ Aq. $\mathrm{AgNO}_{3}$ solution (kept in brown bottle).

(iv) Silver cobalt nitrate Reagent: (a) 25 gm of crystalline cobalt nitrate was dissolved in $50 \mathrm{ml}$ of distilled water. To this $12.5 \mathrm{ml}$ glacial acetic acid was mixed. (b) $120 \mathrm{gm}$ of Sod. Nitrite was dissolved in $180 \mathrm{ml}$ 
water and then $210 \mathrm{ml}$ of (B) was added to solution (A). the mixture was placed on hood \& air was passed through the solution to drive out the fumes of nitrous oxide. This solution is stable for only one month if stored in refrigerator \& filtered every time before use.

(v) Wash reagent : 2 vol of 95\% Alcohol +1 vol. of Ether +2 vol. of water were mixed.

(vi) $\quad 50 \% \mathrm{HCl}$

(vii) Sulfa nilamide solution: $0.5 \mathrm{gm}$ pure powder of sulfanilamide was mixed with a mixture of $30 \mathrm{ml}$ acetic acid \& $70 \mathrm{ml}$ water. Stable for only one week.

(viii) Naphthyl ethylendiamine reagent: 0.1 gm N-(1-Naphthyl)-ethylendiamine dihyrochloride was dissolved in a mixture of $30 \mathrm{ml}$ acetic acid \& $70 \mathrm{ml}$ water. Stable for only one weak.

(ix) Standard Potassium solution $(1 \mathrm{mg} / \mathrm{ml}): 0.223 \mathrm{gm}$ pure dry Pot. Sulphate was dissolved in $100 \mathrm{ml}$ water \& preserved with little toluene working standard solution $0.01 \mathrm{mg} / \mathrm{ml}$. ( $1 \mathrm{ml}$ stock was diluted to 100 $\mathrm{ml}$ with water).

\section{Procedure:}

$0.5 \mathrm{ml}$ serum was mixed with $7 \mathrm{ml}$ distilled water. Now $1 \mathrm{ml}$ of $1.5 \%$ Sod. Tungstate was mixed by tapping, followed by mixing $1 \mathrm{ml}$ of 2.5\% $\mathrm{CuSO}_{4}$ solution corked \& mixed by shaking. Again $0.5 \mathrm{ml}$ of 2.5\% $\mathrm{AgNO}_{3}$ solution was mixed by shaking \& allowed to stand for 20 minutes. Filtered twice to obtain a clear filtrate. $3 \mathrm{ml}$ of the filtrate was taken in a $15 \mathrm{ml}$ graduated conical centrifuge tube and in a second similar tube. $3 \mathrm{ml}$ of working standard Potassium solution was taken. To each tube, $1 \mathrm{ml}$ of $95 \%$ alcohol \& $1 \mathrm{ml}$ of distilled water was added \& mixed by tapping. Both tubes were placed in water bath at $20^{\circ} \mathrm{C}$ (slight warming) for 5 minutes. To each tube, $2 \mathrm{ml}$ of freshly prepared \& filtered silver cobalt nitrate reagent was added mixed \& kept for 20 minutes in water bath. Centrifuged for 15 minutes at $3000 \mathrm{rpm}$. Now supernatant fluid down to 0.2 mark (in centrifuge) were taken out carefully with a capillary pipette $7 \mathrm{ml}$ wash reagent was added through the wall of the centrifuge tube without disturbing the precipitate. Again centrifuged for 15 minutes the supernatant was decanded, \& the centrifuge tubes were inverted on a filter paper pad for 5 minutes washing was repeated twice.

To the washed precipitates in the centrifuge, tubes $10 \mathrm{ml}$ of $0.2 \mathrm{~N} \mathrm{NaOH}$ was added in each tube and mixed the precipitate. Thereafter the tubes were placed on boiling water bath for 10 minutes, removed, cooled \& made up to $10 \mathrm{ml}$ with distilled water mixed well \& centrifuged. $2 \mathrm{ml}$ of supernatant was transferred to $100 \mathrm{ml}$ volumetric flask. To this, $5 \mathrm{ml}$ water was added, followed by $1 \mathrm{ml}$ of $50 \% \mathrm{HCl} \& 2 \mathrm{ml}$ of $0.5 \%$ sulfanilamide solution. Mixed \& allowed to stand for 3 minutes. Now $1 \mathrm{ml}$ of Naphthylethy lenediamine reagent was added and diluted up to 100 mark with water. Allowed to stand for 5 minutes. The solutions were read at 530 filter using a blank prepared by treating $2 \mathrm{ml}$ of water in $100 \mathrm{ml}$. vol. flask by the procedure described above for $2 \mathrm{ml}$ supernatant from the alkali treatment.

Calculation: $\frac{\text { OD Unknown }}{\text { OD Standard }} \times 0.03 \times \frac{10}{3} \times \frac{100}{0.5} \mathrm{mgK} / 100 \mathrm{ml}$ serum




\section{RESULTS AND DISCUSSION}

The fish under study, Clarias batrachus (Linn.), commonly known as "MAGUR" does not show any difference in their colour pattern between male \& female. However, during June to August the belly (abdomen) of female became large rounded due to mature ovary, whereas, the males remain sleek and slender. If pressed laterally, they (female) showed protruded vent and eggs came out. In females the urinogenital papilla is short with large broad base, whereas in males the papilla is prominently large and elongated in sexually mature condition. Colour is uniform brown or grayish black. Males are smaller than females and number of males is less than females.

The gonadal index was calculated to be lowest in November to January i.e. $0.15 \pm 0.003 \mathrm{gm} / \mathrm{cm}$ for male in December while it was $0.54 \pm 0.003 \mathrm{gm} / \mathrm{cm}$ in January for female fish, whereas maximum value was obtained in August $0.75 \pm 0.003 \mathrm{gm} / \mathrm{cm}$ for male \& $0.89 \pm 0.004 \mathrm{gm} / \mathrm{cm}$ for female in July. Similarly, the G.S.I. for male was recorded lowest in November/December (1.8 to 2.08\%) and in January $2.34 \%$ for female. Thus, the weight of the testes \& ovary, length of the gonads (both testes \& ovary), ovarian-index and G.s.I. show parallelism in their activities as with the increase of gonad weight, all these parameters also increases.

The female reproductive system of the fish consisted of a paired ovary. The anterior end of which was free but posteriorly, it tapered \& continued as distinct thick walled oviduct. The left ovary was slightly smaller in length but width was slightly larger than the right ovary. During immature condition, the ovarian wall was smooth \& thick, but with the development or maturation, the wall gradually became thin \& rough (bulging due to formation of larger number of maturing ova). The colour, shape \& size also varied with the stages of ovarian cycle as it was light cream coloured during immature to dirty reddish/dark coloured during mature conditions. Thus, the ovary of C.batrachus. is of "Cystovarian" type as ovocoel continued posteriorly to form oviduct.

In most teleosts, the reproductive activity is rhythmic \& breeding phase becomes restricted to a particular month (s.) or period of the year. Several workers have reported the spawning periodicity in different fishes notably: Ghosh \& Kar (1952) in H.Fossilis; Sathyanesan (1959 a \& b) in Cirrhina reba and Mystus seenghala respectively; Sundaraj (1959 \& 1960) in H. fossilis; Mathur (1962) in Barbus stigma; Bist (1974) and Bist \& Joshi (1975) in Schizothorax richardsonii; Thakur (1978) and Gupta (1996) in C.batrachus; Kumar (1986) in A. testudineus and Treasurer (1990) in Esox lucius. Marza (1938) observed three modes of the maturation of oocytes: Total Synchronism, in which all oocytes develop simultaneously at the same time \& fish spawn only once in its life span; Partial synchronism, in which the fish spawn only once a year with a short \& definite season and consisting of two groups of oocytes and Asynchronism in which the ovary contains several batches of oocytes of different stages of development, indicating a long spawning season. On the other hand, Prabhu (1956) classified spawning into four types; Spawning only once a year for a short duration; spawning only once a year with a long duration; spawning more than once a year and spawning throughout the year. 


\section{CONCLUSION}

In the present study, chloride, sodium \& potassium contents in the blood of male \& female C. batrachus were found lowest during resting phase i.e. during winter months. They gradually increased with the increase of water temperature \& day length and became maximum during spawning period as the increase were found statistically significant $(\mathrm{P}<0.05)$ during spawning period in chloride contents, and $(\mathrm{P}<0.01)$ in sodium \& potassium contents when compared with the value of resting phase.

Thereafter the level declined during post spawning phase. Further, the females have comparatively higher level of chloride, sodium \& potassium contents in their blood then the males but the difference was found statistically significance only during prespawning \& spawning periods in the case of sodium and during preparatory \& prespawning periods in potassium contents. Contrary to this, calcium and magnesium contents in the blood were recorded highest during resting phase in both sexes which gradually and significantly decreased \& became lowest during spawning phase followed by a rise during pre-spawning phase. Further, in females, the calcium level in blood was found significantly higher than the males while magnesium level were also found higher in female, but it was not found significant at any stage when compared with the males. Thus, the increase/decrease of these ions was comparatively more dependent on the environmental factors. However, influence of some hormones like prolactin and oestradiol in the regulation of chloride \& calcium cannot be ruled out.

\section{References}

1. Agarwal, A. 1982: Studies on the karyotype \& histological changes in the gonads of some fishes of Jammu \& Kashmir, Ph.D. Thesis Univ. of Jammu.

2. Banerjee, S. and Banerjee, V. 1987 b: Erythrocytes and related parameters in Heteropneustes fossilis (Bloch) with special reference to body length, sex \& season J. Adv. Zool., 8(2): 67-72.

3. Bentley, P.J. and Follett, B.K. 1965: Fat and carbohydrate reserves in the river lamprey during spawning migration. Life. Sci. 4 : 2003-2007.

4. Billard, R. and Marcel, J. 1986: Aquaculture of cyprinids. I.N.R.A., Paris.

5. Bohemen, C.G.; Lambert, J.G.D. and peute, J. 1981: Annual changes in plasma \& liver in relation to vitellogenesis in the female rainbow trout, Salmo gairdneri. Gen. Comp. Endocrinol., 44: 94-107.

6. Chatterjee, P.K., Kumar, A. \& Sinha, N.D.P. 1991 : Gonadal cycle \& ovarian electrolyte behavior in air breathing teleost Channa punctatus (Bloch) and Heteropneustes fossilis (Bloch). J.Freshwater Biol. 3(a) : 37-44.

7. Dietschy, J.M. and Wilson, J.D. 1970 : Regulation of cholesterol metabolism. New. Eng. J. Med. 282 : 1128-1249.

8. Emmersen, B.K. \& Patersen, I.M. 1976: Natural occurrence and experimental induction by estradiol 17-B of a lipopho-phoprotein (Vitillogenin) in flounder, Platychtys flessus L. Comp. Biochem. Physiol. 54(B): 443-446.

9. Gupta, S.K. 1996: Some histochemical \& biochemical studies on the development of female reproductive organ of an air-breathing fish. Clarias batrachus (Linn.) and its relation with Thyroid follicles. Ph.D. 
Thesis, B.R.A.B.U., Muza., India.

10. Guraya, S.S.; Kaur, R. \& Saxena, P.K. 1975 : Morphology of ovarian changes during the reproductive cycle of fish, Mystus tengara (Ham). Acta. Anat., $91: 222-260$.

11. Jaiswal, D.M.; Belsare, S.D. and Belsare, D.K. 1978: Correlative changes in hepatic and serum cholesterol during annual ovarian cycle in the Catfish, Heteropneustes fossilis (Bloch.). Bioresearch, 2(1) : 37-41.

12. Jonas, R.E.E. and MacLeod, R.A. 1960 : Biochemical studies on sockeye salmon during spawning migration X. Glucose, total protein, non-protein nitrogen and amino acid nitrogen in plasma. J. Fish. Res. Bd. Can. 17 : 125-126.

13. Joshi, B.D. 1980: Sex-related cyclic variations in blood glucose and cholesterol contents of a cat fish. Comp. Physiol. Ecol., 5(a): 13-16.

14. Joshi, B.D. 1982: Circannual fluctuation in some blood components of the fish, Rita rita in relation to certain ecophysiological conditions. Uttar Pradesh. J. Zool. 2 : 62-66.

15. Joshi, B.D. and Tandan, R.S. 1977: Seasonal variations in some haematological values of fresh water fishes I : H. fossilis and M. vittatus. Comp. Physiol. Ecol. 2 : 2-26.

Cite this Article

Dr. Amit Kumar, "Study of Iron, Inorganic Phosphate, Sodium, Potassium in Serum and its Effects on Reproduction of the Experimental Fish Clarias Batrachus ", International Journal of Scientific Research in Science and Technology (IJSRST), Online ISSN : 2395-602X, Print ISSN : 2395-6011, Volume 7 Issue 5, pp. 307314, September-October 2020. Available at doi : https://doi.org/10.32628/IJSRST207567 Journal URL : http://ijsrst.com/IJSRST207567 